\title{
Use of Glauconite in Potato Cultivation Technology
}

\section{Irina Gasparyan, Marina Dyikanova ${ }^{1}$, Alexander Levshin ${ }^{1}$, Andrey Kalilets ${ }^{2}$, and Roman Korshunov² \\ ${ }^{1}$ Russian State Agrarian University - Moscow Timiryazev Agricultural Academy, Moscow, Russia ${ }^{2}$ CJSC Logistic, Moscow, Russia}

\section{Abstract}

In intensive technologies of cultivation of potatoes, the need for trace elements is increasing. The concentration of trace elements in plants is very small, but the importance of these elements in biochemical processes is difficult to overestimate. The deficiency of trace elements is the root cause of many functional disorders. Trace elements in plants are part of enzymes, stimulate and accelerate plant development, increase resistance to adverse environmental conditions, etc. Also, with their shortage, crop productivity decreases. The use of natural minerals, such as glauconite, containing trace elements, allows improving comprehensive nutrition and increase productivity. Getting early production of high quality potatoes in the summer is important and relevant in the modern world. The use of glauconite in the conditions of the Moscow region, along with fertilizers and irrigation, allows obtaining high-quality products and increasing productivity by $6.3 . . .29 .0 \%$.

Received: 25 October 2019

Accepted: 15 November 2019

Published: 25 November 2019

Publishing services provided by Knowledge E

(c) Irina Gasparyan et al. This article is distributed under the terms of the

\section{Introduction}

In recent years, there has been an increase in the productivity of agricultural plants due to the introduction of high-yielding varieties and the intensification of agriculture. There is an increase in the use of highly concentrated fertilizers, the volume of organic fertilizers is reduced, and there is an imbalance of nutrients. In this connection, it is necessary to pay more and more attention to the regulation of nutrition of crops. The introduction of macronutrients pays great attention, and the introduction of trace elements is insufficient, the deficit of one or more elements is observed quite often in agriculture. The application of balanced nutrition of plants containing trace elements is relevant and important at the present time.

The concentration of trace elements in the tissues of plants or animals is extremely small, but the importance of these elements in biochemical processes is difficult to S OPEN ACCESS overestimate. In recent years, there has been increased attention to ecological nutrition 
and the content of essential trace elements in food products, as trace deficiency is the root cause of many functional disorders [1-2]. Trace elements in plants are part of enzymes, stimulate and accelerate plant development, increase plant resistance to adverse environmental conditions, etc.

At the deficit of elements in the soil, there will certainly be a deficit of these elements in agricultural products. When regulating all factors in intensive technology, the limiting factor will be trace elements. In the Moscow region there are mainly sod-podzolic soils, according to some scientists, the content of trace elements in them is quite low [3]. In this regard, the study of glauconite containing trace elements and their use on sodpodzolic soils of the Moscow region is very important and the use of glauconite in the technology of cultivation of early potatoes containing trace elements will increase yield.

\section{Methods and Equipment}

The studies were carried out in 2018--2019 years on the area of the laboratory of vegetable growing RGAU-MSHA named after K.A. Timiryazev. Soils are soddy-podzolic heavy loamy, the thickness of the arable layer is $20 \ldots .22 \mathrm{~cm}$, easily hydrolyzed nitrogen is $14.0 \mathrm{mg}$ per $100 \mathrm{~g}$ of soil, phosphorus -- 16.0, potassium -- $20 \mathrm{mg}$ per $100 \mathrm{~g}$ of soil.

The experiments were carried out 3 times. Variants in the experiment were placed by a randomized method. The area of one experimental plot is $25 \mathrm{~m}^{2}$. Planting scheme $--70 \times 35 \mathrm{~cm}$. The variety Luck and glauconite of the Bondarsky field of the Tambov region were used, the norm is from 20 to 40 grams per 1 plant.

Glauconite, or glaucony, is a layered magnesium-ferruginous hydromica a. It has a chemical composition: potassium oxide $\left(\mathrm{K}_{2} \mathrm{O}\right)$ is 4.4...9.4 percent, sodium oxide $\left(\mathrm{Na}_{2} \mathrm{O}\right)$ $0 . .3 .5 \%$, aluminum oxide $\left(\mathrm{Al}_{2} \mathrm{O}_{3}\right) 5.5$ to $22.6 \%$, the iron oxide $\left(\mathrm{Fe}_{2} \mathrm{O}_{3}\right)$... of $6.1 \%$ and $27.9 \%$, iron oxide $(\mathrm{FeO})$ 0.8...8.,6\%, magnesium oxide $(\mathrm{MgO}) 2.4 \ldots 4.5 \%$, silicon dioxide $\left(\mathrm{SiO}_{2}\right) \ldots 47.652 .9 \%$, water $\left(\mathrm{H}_{2} \mathrm{O}\right)$ of $4.9 . .13 .5 \%$. Glauconite contains a high amount of potassium (4.4...9.4\%), which is able to quickly break down with the release of potassium in the form of easily digestible compounds, as well as trace elements [2--4]. Glauconite has high adsorption and cation exchange properties (their specific surface -- 40...100 $\mathrm{kg} / \mathrm{g}$, exchange capacity -- $15 . .20 \mathrm{mg} / \mathrm{EQ}$ per $100 \mathrm{~g}$ of rock), Sorbs the outer surface, and porosity is due to gaps between contacting particles [4-6].

Granulometric composition is mainly represented by fraction -- $0.5+0.001 \mathrm{~mm}$ (up to $93 \%)$. The percentage of glauconite increases in small fractions. Grain sizes vary from 0.02 to $20 \mathrm{~mm}$. grain Shape is varied, the content of glauconite on average $47 \%$. There is significant in the Sands of montmorillonite and fine organic matter [7--8]. 
Planting was carried out at a time when the soil warmed up to $6 \ldots 8{ }^{\circ} \mathrm{C}$. The drip was watering. The cultivation technology was standard. Cleaning was carried out in two terms: July 15 and July 30.

\section{Results}

To provide the Moscow region with table potatoes in the summer, it is possible to use glauconite in the cultivation technologies. Glauconite is a mineral in the form of microaggregate grains ranging in size from 0.01 to $0.8 \mathrm{~mm}$, it contains trace elements: manganese, copper, cobalt, nickel, boron, vanadium, phosphorus and potassium, etc. Glauconites have high adsorption and cation exchange properties that allow moisturing to be retained.

The effect of glauconite on the yield of early potatoes was investigated (Table 1). TABLE 1: Potato yield c. Luck, on average for 2018--2019 years.

Option
Control without watering
Glauconite $20 \mathrm{~g} /$ rast.
Glauconite $30 \mathrm{~g} /$ rast.
Glauconite $40 \mathrm{~g} /$ rast.
$\mathrm{SSD}_{05}$

\begin{tabular}{|c|c|}
\hline \multicolumn{3}{|c|}{ Cleaning on 07/30 } \\
\hline g/rast. & $\% \pm$ to control \\
\hline 940 & -- \\
\hline 1000 & $+6,3$ \\
\hline 1100 & $+17,0$ \\
\hline 1210 & $+28,0$ \\
\hline 47,81 & \\
\hline
\end{tabular}

\section{Discussion}

According to table 1 , it is clear that when glauconite is added to early potato cultivation technologies while satisfying all plant needs, but without additional watering, the yield increases from 6.3 to $28.0 \%$. The maximum increase occurred when adding to the hole when planting potatoes glauconite in a dose of $40 \mathrm{~g}$ per 1 plant.

Potatoes have high demands on soil moisture. And this need changes depending on the growth and development of the plant. The maximum demand is observed during the period of "budding -- mass flowering". According to some authors, even short-term droughts and lack of moisture in the soil during this period lead to the most severe decrease in productivity [9--10]. On dry land, potato yield is determined by rainfall.

Drought during flowering and tuber formation has a greater impact on crop decline than in the period of cessation of growth of tops. During flowering and tuber formation, 
it has a greater negative impact on the number of tubers formed. With a lack of moisture during flowering, there is also a decrease in the mass of tubers. In case of drought in the period of tuber formation, the plant retains the ability to further grow. The high moisture content at this time contributes to the growth of tubers, but they are formed with low dry matter content, tubers have a loose rind and the associated poor quality and poor keeping quality [11].

Potatoes have a weak cuticle and low osmotic pressure -- a plant of hygrophilous type, i.e. more adapted to humid conditions. It is very sensitive to sudden changes in temperature and humidity. Therefore, in many regions, the provision of water is the main task to achieve stable and high yields, especially during the tuber formation period. A day potatoes it takes $5 . . .6 \mathrm{~mm}$ of water from the soil moisture reserve [12--13].

In Central Europe, early potatoes with a short growing season needs moisture from mid-may to late June, in mid -- early varieties this period from June to July, and later-from July, August and the first half of September. In the growing season of 2019, the month of June was dry and hot [14--15].

Due to the uneven provision of moisture for potato plants, especially in recent years, when there are sharp temperature changes and heavy rains, alternating droughts, thunderstorms, etc., it is necessary to ensure soil moisture at the level of $60 \ldots 80 \%$ of the maximum field moisture capacity. At the experimental site, small-drop irrigation was carried out, which provided this humidity. As a result, a potato crop was obtained at an earlier date -- July 15 (data are presented in table 2).

TABLE 2: Potato yield c. Good luck with watering on average for 2018--2019 years.

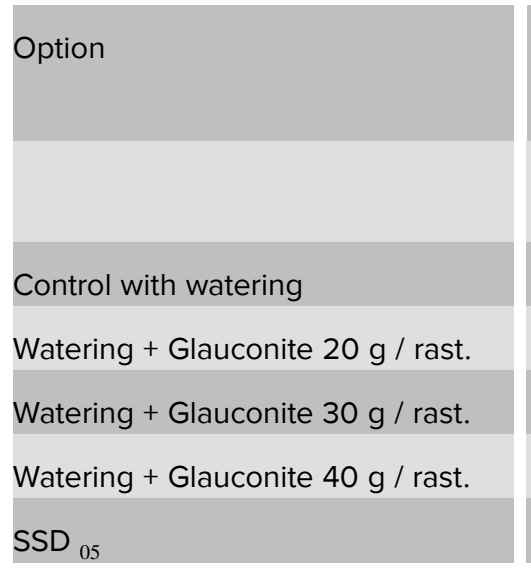

\begin{tabular}{|c|c|}
\hline Cleaning on $07 / 15$ \\
\hline g / rast. & $\begin{array}{l}\% \pm \text { to } \\
\text { control }\end{array}$ \\
\hline 830 & -- \\
\hline 1100 & $+32,5$ \\
\hline 1200 & $+44,6$ \\
\hline 800 & $--3,0$ \\
\hline 44,20 & \\
\hline
\end{tabular}

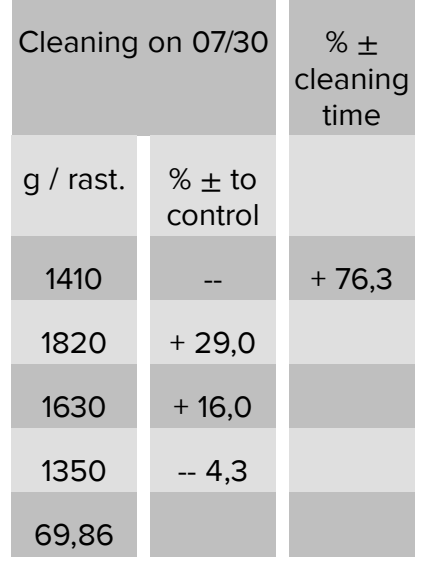

According to table 2 , it can be seen that when the plant is provided with all the necessary factors, the average potato yield per plant is rather high (830 g / plant) even when harvesting on July 15 . This fully justifies the cultivation of early products, since during this period, mainly in the market, the price of fresh potatoes is high. 


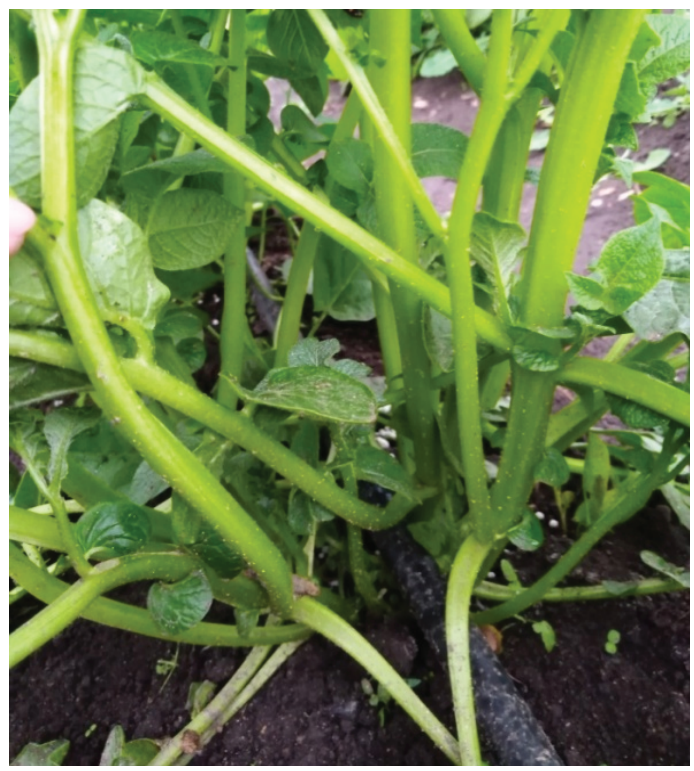

a)

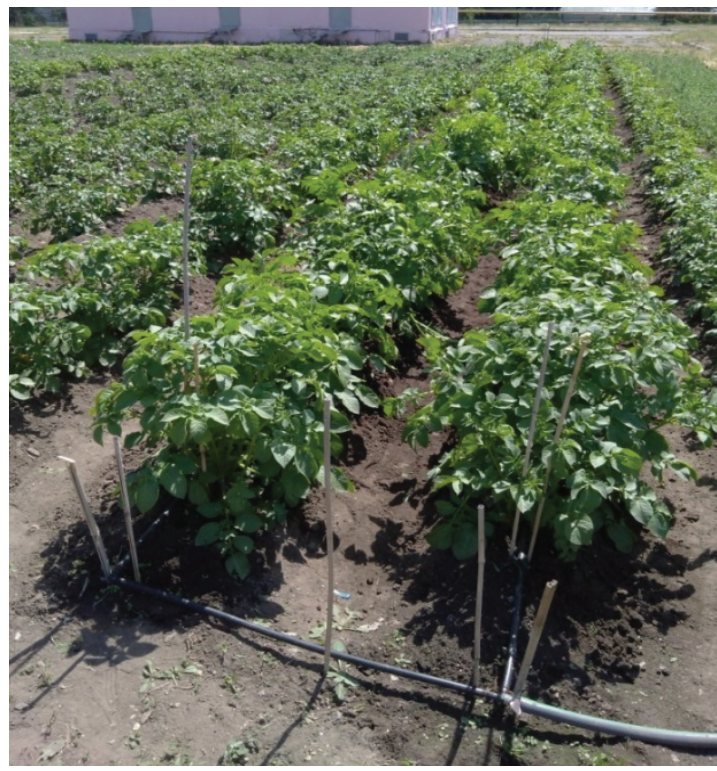

b)

Figure 1: Plants with atomized watering: number of shoots per 1 plant (a), the variants with irrigation in the month of June (b).

When harvesting at the usual time for the Moscow region early potato yield with irrigation without the use of minerals was 1410 grams per 1 Bush. When adding the mineral 20 grams per 1 Bush yield increased by $29 \%$ and amounted to 1820 grams per Bush. This is a high yield in this period. Without watering during this period with the use of minerals, the maximum yield was 1210 grams per Bush. Watering is a limiting factor in such hot years. Providing all the necessary factors, it is possible to improve nutrition due to trace elements, the law of minimum works here. Any additional costs without taking into account the factor that is at a minimum, are meaningless, can not give the desired effect. Therefore, in the near future limiting the development of productivity will be the presence of moisture.

Adding glauconite at harvest in the 2 nd period the yield increased by 16.0...29 \%. The maximum increase in yield was observed with the introduction of glauconite in the norm of $20 \mathrm{~g} / \mathrm{rast}$. minimum with a minimum $30 \mathrm{~g} / \mathrm{plant}$., with an increase in the further rate there is a decrease in the yield.

Plants with irrigation was formed more stems (Future 1--2), and as is known there is a correlation between the number of tubers formed and stems or shoots [13].

Crop with irrigation was higher than without irrigation, as the average daily weight gain of tubers per Bush can be according to some scientists $[10,13,15] 30 . .35 \mathrm{~g}$ during tuber formation (for early varieties in our zone June). This year there was a drought during this period, but the temperature was favorable for photosynthesis $\left(22 \ldots 25^{\circ} \mathrm{C}\right)$, so in the variants with irrigation the yield was high. 


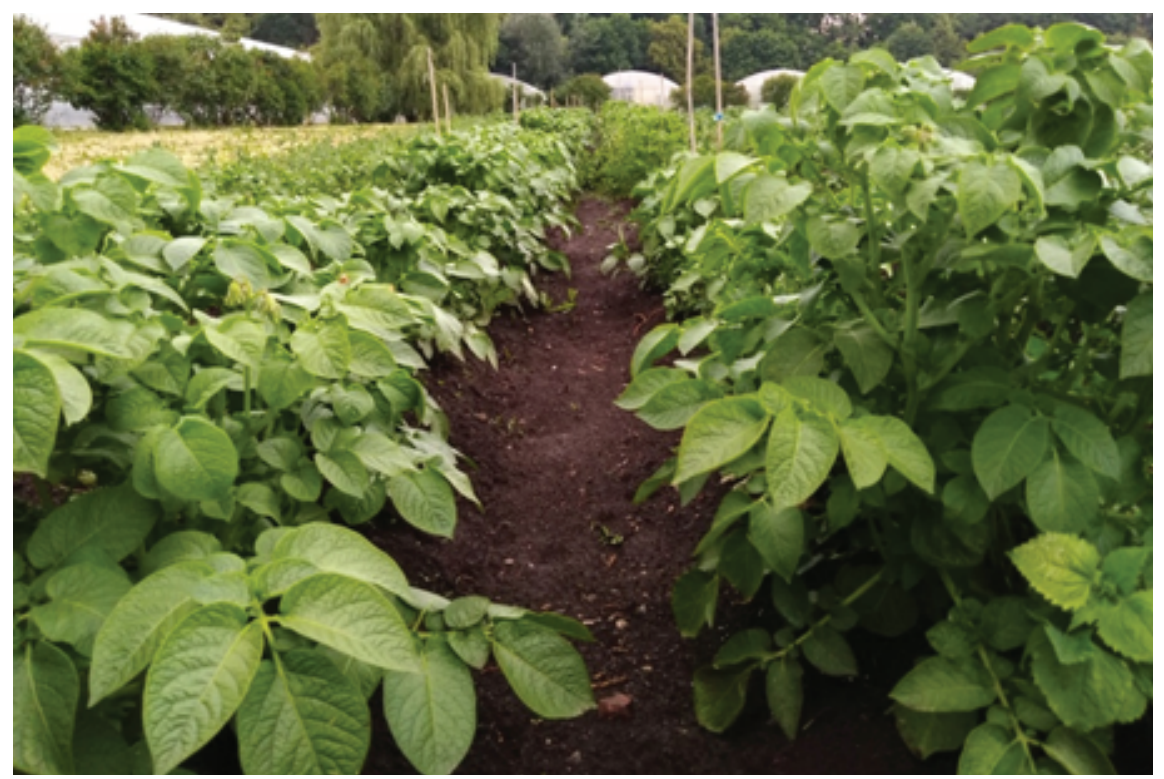

Figure 2: Options with watering (right) and without watering (left).

With the addition of glauconite containing trace elements, productivity increased by $16.0 . . .29 \%$. The maximum increase in yield was observed with the introduction of glauconite in the norm of $20 \mathrm{~g} / \mathrm{rast}$., the minimum -- with the introduction of $30 \mathrm{~g} / \mathrm{rast}$. With an increase in the further norm, the yield decreases.

It is assumed that this increase is associated with an improvement in the nutrition of plants with elements, including due to the content of potassium oxide in glauconite, which, according to Levchenko M.L. [7] is contained in the glauconite of the Bondar deposit used in the experiment. Glauconite in the soil is rapidly destroyed and released in the form of easily digestible compounds. Also, glauconite contains phosphorus in small concentrations and trace elements such as boron, manganese, magnesium, etc.

\section{Conclusion}

Thus, the use of glauconite helps to increase yields from 6.3 to 29.0 depending on the norm and allows getting high early potato yields. Glauconite is a natural mineral that contains phosphorus in small concentrations and trace elements such as calcium, boron, manganese, sulfur, magnesium, etc. According to other researchers, glauconite is a sorbent [4--7] and with the increasing share of agrochemicals and pesticides in intensive technology, it will reduce the pollution of agricultural land, being a natural adsorbent. 


\section{Funding}

The work was carried out in accordance with the thematic plan of research works Russian State Agrarian University -- Moscow Timiryazev Agricultural Academy

\section{Acknowledgement}

The authors would like to express gratitude to their colleague for their contribution and support to the research. They are also grateful to all the reviewers who gave their valuable inputs to the manuscript and helped in completing the paper.

\section{Conflict of Interest}

The authors have no conflict of interest to declare.

\section{References}

[1] Lisitsyn, A.B. et al. (2009). Conceptual Approaches to the Creation of a Food Safety System. Food industry, no. 12, pp. 39--41.

[2] Lisitsyn A.B. et al. (2007). Organic product. Moscow: VNIIMP them. V.M. Gorbatov, $131 \mathrm{p}$.

[3] Kulakovskaya, T.N. (1990). Optimization of the agrochemical system of soil nutrition of plants. Moscow: Agropromizdat, 218 p.

[4] Birch, G.F., Willis, J.P., and Rickard, R.S. (1976). An electron microprobe study of glauconites from the continental margin off the west coast of South Africa. Marine Geology, vol. 22, pp. 271--283.

[5] Blott, S.J. (2000). GRADISTAT (Version 4): A Grain Size Distribution and Statistics Package for the Analysis of Unconsolidated Sediments by Sieving or Laser Granulometer. Retrieved from: http://www.kpal.co.uk/gradistat_abstract.htm; last accessed 26 July 2007).

[6] Bornhold, B.D., Giressse, P. (1984). Glauconitic sediments on the continental shelf off Vancouver Island, British Columbia, Canada. Journal of Sedimentary Petrology, vol. 55, pp. 653--664.

[7] Levchenko, M.L. (2008). Features of glauconite from the Bondarsky deposit in the Tambov region. VGU Bulletin, Series Geology, no. 1. pp. 65--69. 
[8] Degefie, D.T., Fleischer, E., Klemm, O., Soromotin, A.V., Soromotina, O.V., Tolstikov, A.V., Abramov, N.V. (2014) Climate Extremes in South Western Siberia: Past and Stochastic Environmental Research and Risk Assessment, vol. 28, no. 8, pp. 2161--2173.

[9] Eremin, D., Eremina, D. (2016). Influence of Granulometric Composition Structure of Anthropogenic-Reformed Soil on Ecology of Infrastructure. Procedia Engineering, vol. 165. pp. 788--793.

[10] Dyikanova, M.E., et al. (2019) The cultivation of early potatoes -- a training manual. Moscow: Publishing House of the Russian State Autonomy and Agricultural Academy named after K.A. Timiryazev, $172 \mathrm{p}$.

[11] Popkova, K.V., Kutsamanova, I.N. (1999). Methods of improvement of potatoes from viral diseases. Proceedings of the Scientific Conference of Young Scientists and Specialists. Moscow: Publishing house of ICCA, pp. 49--54.

[12] Levshin, A.G. (2019). Constructive Features of the Device to Remove the Apical Shoots of Potatoes. 18th International Scientific Conference "Engineering for Rural Development" (22--24.05.2019 Jelgava, LATVIA), pp. 532--537. Retrieved from: www.tf.Ilu.Iv/conference/proceedings 2019

[13] Pisarev, B.A. (1986). Production of early potatoes. Moscow: Rosselkhoznadzor, 287 p.

[14] Gasparyan, I.N. (2018). Biology with basics of ecology. Moscow: Publishing house RGAU-MSHA named after K.A. Timiryazev, 331 p.

[15] Soloviev, A.M., et al. (2014). Application of fertilizers in the cultivation of crops with high technology. Moscow: Publishing house RGAU-MSHA named after K.A. Timiryazev, $132 \mathrm{p}$. 